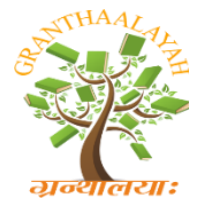

\author{
INTERNATIONAL JOURNAL OF RE
GRANTHAALAYAH \\ A knowledge Repository
}

Science

\title{
YIELD, YIELD COMPONENTS AND QUALITY OF GROUNDNUT (ARACHISHYPOGAEA L.) AS INFLUENCED BY INTER ROW SPACING AND WEEDING FREQUENCY
}

\author{
Biftu Umer Mohammed ${ }^{1}$, Besufikad Enideg Getnet ${ }^{2}$ \\ ${ }^{1,2}$ Gambella University College of Agriculture and Natural Resource, Department of Plant
}

Sciences, Gambella, Ethiopia

\begin{abstract}
Proper planting density and weeding playan important role on proper growth, productivity and quality of crops. The present study was undertaken to evaluate effect of inter row spacing and weeding frequency for their phenologycal parameter, yield and yield component and quality parameter at Gambella University College of Agriculture and natural resource, South West Ethiopia. Four level of inter row spacing and four level of weeding frequency were evaluated in randomized complete block design with three replication. The interaction effect of inter row spacing and weeding frequency showed significant variation both phenologycal performance yield and yield component as well as quality parameter. Among the treatment tested a combination of $70 \times 10 \mathrm{~cm}$ spacing with three times weeding registered $49.867 \mathrm{~cm}$ of plant height. Early flowering 31.883 days maturity 136.693 days and high LAI 4.546 were observed on treatment combination of $40 \times 10 \mathrm{~cm}$ and zero weeding. In terms of yield and yield component, higher number of pod per plant 45.003 , dry pod yield $2909.47 \mathrm{~kg} / \mathrm{h}$ and seed yield $2360.15 \mathrm{~kg} / \mathrm{ha}$ were observed on $60 \mathrm{x} 10$ spacing with two times weeding treatment combination. On the other hand, highest harvest index $28.41 \%$ was observed from three times weeding frequency. However, number of seed per pod shows none significant effect. Furthermore, interims of quality parameter oil content $32.483 \%$ were observed on three times weeding frequency and highest protein content $20.816 \%$ and $19.2833 \%$ were observed from three times weeding frequency and 70x $10 \mathrm{~cm}$ spacing respectively. Generally according to the result of the study spacing of $60 \times 10 \mathrm{~cm}$ with twice weeding at 10 days interval can be recommended for groundnut production in Gambella. However, this is one time and one location experiment therefore it should have to be repeated in different location and season to get reliable result.
\end{abstract}

Keywords: Inter Row Spacing; Weeding Frequency; Yield; Quality.

Cite This Article: Biftu Umer Mohammed, and Besufikad Enideg Getnet. (2019). "YIELD, YIELD COMPONENTS AND QUALITY OF GROUNDNUT (ARACHISHYPOGAEA L.) AS INFLUENCED BY INTER ROW SPACING AND WEEDING FREQUENCY." International Journal of Research - Granthaalayah, 7(11), 294-306. 


\section{Introduction}

Groundnut or peanut (ArachishypogaeaL.) thatbelongs to family Leguminosaegenus Arachisis the fourth world's principal oil seed crops (FAO, 2011). It is grown about one hundred countries in the world intropical and sub-tropical part over 20 million hectares. The total annual world production is about 25 million tons of unshelled nuts, $70 \%$ of which is contributed by India, China and U.S.A. (Khidir M. O.,1997), (Elobied S., (2010). Groundnut is an excellent source of plant nutrients containing 45-50\% oil, 27-33\% protein as well as essential minerals and vitamins. It plays an important role in the dietary requirements of resource for poor women and children. In addition, haulms are used as livestock feed (Elobied, S.,2010).

Groundnut, or peanut, is commonly called the poor man's nut. This plant is native to South America and has never been found uncultivated. Groundnut is an upright or prostrate annual plant. It is generally distributed in the tropical, sub-tropical and warm temperate zones. Ethnological studies of the major Indian tribes of South America document the widespread culture of groundnut and provide indirect evidence for its domestication long before the Spanish conquest. When the Spaniards returned to Europe they took groundnuts with them. Later traders were responsible for spreading the groundnut to Asia and Africa (Gibbonset al., 1972).

Groundnut is relatively new to Ethiopia. It was introduced from Eritrea to Hararghe in the early 1920s by Italian explorers (Daniel, E. 2009). Major groundnut producing areas in Ethiopia are Babile, Gursum, Beles, Didessa, Gambella and Pawe. Whereas, GamuGofa, Illubabor, Gojam, Wello and Wellega are identified as potential production areas (Daniel E., 2009). In Ethiopia in the year of 2014 it was cultivated on 79,943.03 ha of land and 112088.7 tons of groundnuts were produced with average yield of 1.402 tons ha-1 (Soliman, I. E. et al., 2015). It is an important food and cash crop in the semi-arid areas of the eastern, western and north-western parts of Ethiopia (CSA, 2012/13). In Ethiopia, groundnut is the second important lowland oilseed of warm climate next to sesame. The lowland areas of Ethiopia have considerable potential for increased oil crop production including groundnut (EARO, 2000).

Groundnut production is affected by different biotic and abiotic factors among them the main problems limiting production of groundnut are poor cultural practices especially the practice of wide spacing as well as inadequate weed management (Elobied, S.,2010). Plant density is an efficient management tool for maximizing grain yield by increasing the capture of solar radiation within the canopy (Monneveux, P.et al., 2005). While the establishment of sole groundnut on wide rows result in sub-optimum plant production densities and often led to lowered yields ha $^{-1}$ due to inefficient utilization of crop growth resources (Konlan S et al., 2013b), (Konlan S et al., 2013a). Proper spacing ensures adequate ventilation, reduces competition among plants for space and nutrients, and reduces transmission of diseases, facilitates weeding and movement in the farm and also reduces overcrowding and, therefore, allows interception of radiation by plant canopies. Gambella Agricultural Research Center has also recommended $60 \mathrm{~cm}$ between rows and $10 \mathrm{~cm}$ between plants for groundnut. However, groundnut in the study area does not use the recommended spacing. Also the competitive ability of groundnut with weed is less particularly 3 - 6 weeks after sowing therefore, early removal of weeds is important before flowering and during pegging (Bedry K. A., 2007). Plant population and weed management is determined by various attributes which are largely under grower control. Generally, correct timing of weeding and proper 
spacingiscommanding in the determination of yield in groundnut cultivation. This study is therefore planned to examine the effect of inter-row spacing and weeding frequency on yield, yield components and quality of groundnut in the study area with the following objectives.

\section{Materials and Methods}

\subsection{Description of the Study Area}

Field experiment was conducted during 2017/18 main cropping season at Gambella University. Gambella is located $776 \mathrm{Km}$ away $7^{0} 5^{\prime} \mathrm{N}$ and $34^{0} 32^{\prime}$ west of the capital Addis Abeba. Annual mean minimum and maximum temperatures in Gambella are $25^{\circ} \mathrm{C}$ and $42^{\circ} \mathrm{C}$, respectively. Mean annual rainfall of the area varies from $800 \mathrm{~mm}$ to $1,500 \mathrm{~mm}$ with a long-term average of $1,400 \mathrm{~mm}$. The site is located at an altitude of 526 m.a.s.l. Most of the soils of the region are fluvisols (alluvial soil type) which have $\mathrm{pH}$ of 6.1 and it is slightly acidic.

\subsection{Treatments and Experimental Design}

Roba groundnut variety which is adapted to Gambella agro-ecological condition and used by most of small scale farmerswas used.Factorial experiment of four weeding frequency ( 0 wedding, 1 weeding, 2 weeding and 3 weeding) in ten days interval with four inter row spacingS $1(40 \mathrm{~cm} \times$ $10 \mathrm{~cm}), \mathrm{S} 2(50 \mathrm{~cm} \times 10 \mathrm{~cm}), \mathrm{S} 3$ plants ha-1 $(60 \mathrm{~cm} \times 10 \mathrm{~cm})$ and $\mathrm{S} 4(70 \mathrm{~cm} \times 10 \mathrm{~cm})$ was tested in Randomized Complete Block Design with three replications. The gross plot size was $3.2 \mathrm{~m} \times$ $2.5 \mathrm{~m}$ for the width and length of the plots, respectively. The distance between each plot was $1 \mathrm{~m}$ while distance between block is $1.5 \mathrm{~m}$ and the total experimental area was $675.24 \mathrm{~m}^{2}$. A single experimental plot have8 rows for $\mathrm{S} 1,6$ rows for $\mathrm{S} 2,5$ rows for $\mathrm{S} 3$ and 4 rows for $\mathrm{S} 4$.

Table 1: Treatment combinations

\begin{tabular}{|c|c|c|c|}
\hline \multirow[t]{2}{*}{ No } & \multicolumn{2}{|c|}{ Treatments } & \multirow{2}{*}{$\begin{array}{c}\text { No of plants } \\
\text { per } \\
\text { hectare }\end{array}$} \\
\hline & Spacing & Weeding frequency & \\
\hline 1 & \multirow[t]{4}{*}{ S1 } & W1 (0 wedding):no weeding & \multirow[b]{4}{*}{250,000} \\
\hline 2 & & W2 (1 time weeding): weeding at $10 \mathrm{DAE}$ & \\
\hline 3 & & W3 (2 time weeding): weeding at $10 \mathrm{DAE}$ and $20 \mathrm{DAE}$ & \\
\hline 4 & & $\begin{array}{l}\text { W4 (4 times weeding): weeding at } 10 \mathrm{DAE}, 20 \mathrm{DAE}, 30 \mathrm{DAE} \\
\text { and } 40 \mathrm{DAE}\end{array}$ & \\
\hline 5 & \multirow[t]{4}{*}{$\mathrm{S} 2$} & W1 (0 wedding):no weeding & \multirow[b]{4}{*}{187,500} \\
\hline 6 & & W2 (1 time weeding): weeding at $10 \mathrm{DAE}$ & \\
\hline 7 & & W3 (2 time weeding): weeding at 10 DAE and 20 DAE & \\
\hline 8 & & $\begin{array}{l}\text { W4 (4 times weeding): weeding at } 10 \mathrm{DAE}, 20 \mathrm{DAE}, 30 \mathrm{DAE} \\
\text { and } 40 \mathrm{DAE}\end{array}$ & \\
\hline 9 & \multirow[t]{4}{*}{ S3 } & W1 (0 wedding):no weeding & \multirow[b]{4}{*}{156,250} \\
\hline 10 & & W2 (1 time weeding): weeding at $10 \mathrm{DAE}$ & \\
\hline 11 & & W3 (2 time weeding): weeding at 10 DAE and 20 DAE & \\
\hline 12 & & $\begin{array}{l}\text { W4 (4 times weeding): weeding at } 10 \mathrm{DAE}, 20 \mathrm{DAE}, 30 \mathrm{DAE} \\
\text { and } 40 \mathrm{DAE}\end{array}$ & \\
\hline 13 & S4 & W1 (0 wedding):no weeding & \\
\hline
\end{tabular}




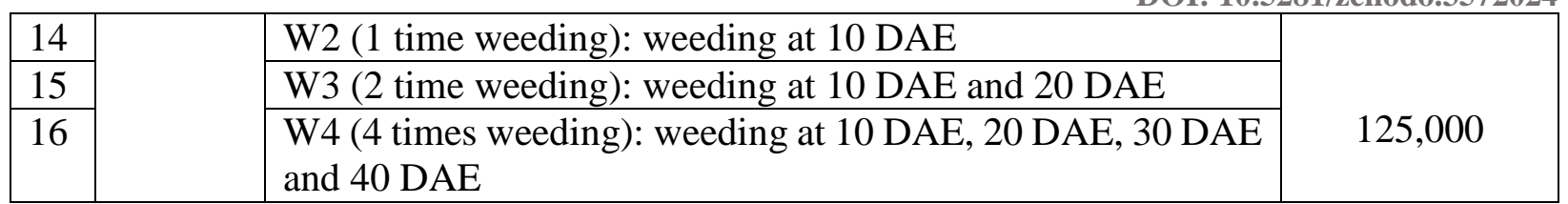

Where: DAE: Days After Emergence

\subsection{Experimental Procedure}

The land was ploughed once, harrowed twice and leveled to obtain the desired germination and growth of crop. The field was then divided into three blocks and then in to $3.2 \mathrm{~m} \times 2.5 \mathrm{~m}$ equal plots as per the treatments. Seeds of groundnut variety (Roba) used for this experiment was obtained from Gambella agricultural research center. The seeds was sown in rows at the depth of 4 $\mathrm{cm}$ having two seeds per hill and then thinned to one plant per hill just a week after emergence. Planting was done on July15/2018.

Weeding was started ten days after emergence and continued at ten days interval. Harvesting was done when the crop reached physiological maturity, i.e. the pods fully veined, kernels have begun to become red in color and the inside of the shells has begun to color brown and show darkened veins. The data was collected from the central rows, by leaving one border rows from each side of a plot and one plant at the two ends of every row. The net plots were harvested by digging out the whole plant with a hoe. Thereafter, the pods were picked from the main bunch and allowed to air and sundry for six days. The dried pods were then collected on plot basis.

\subsection{Data Collected}

Data such as Plant height (cm), Days to 50\% flowering, Days to 90\% maturity, Leaf area, Number of pods per plant, Number of seeds per pod, Hundred seed weight, Dry pod yield, Seed yield $(\mathrm{Kg} / \mathrm{ha})$, Harvest index (\%), Oil and protein content of the seedwere recorded. The collected data were subjected to analysis of variance using SAS statistical software package 9.2 (SAS, 2008). The differences between treatment means was compared using least significance difference (LSD) test at $5 \%$ level of significance.

\section{Result and Discussion}

\subsection{Effect of Inter-Row Spacing and Weeding Frequency on Phenological Parameters}

\subsubsection{Plant Height}

Analysis of variance of the data revealed that the interaction effect of inter-row spacing and weeding frequency was highly significant $(\mathrm{P}<0.01)$ on plant height of groundnut (Appendix table 1). Plant height ranges from $30.34 \mathrm{~cm}$ in $40 \times 10 \mathrm{~cm}$ and zero times weeding to $49.87 \mathrm{~cm}$ in $70 \times 10 \mathrm{~cm}$ spacing with three times weeding (Table 2). The difference in plant height observed in this experiment could be due to less interspecific competition for available resources in weed-free treatment and wider spacing which facilitates plants to have more resources for growth. Plant height increased linearly with wider row spacing as a result of reduced interspecific competition. 
Table 2: The interaction effect of inter-row spacing and weeding frequency on plant height of groundnut (cm)

\begin{tabular}{|l|c|c|c|c|}
\hline \multirow{2}{*}{ Weeding frequency } & \multicolumn{4}{|c|}{ Spacing } \\
\cline { 2 - 5 } & $\mathbf{4 0 \times 1 0 c m}$ & $\mathbf{5 0 x 1 0 c m}$ & $\mathbf{6 0 x 1 0 c m}$ & $\mathbf{7 0 x 1 0 c m}$ \\
\hline No weeding & $30.34^{\mathrm{j}}$ & $38.827^{\text {cde }}$ & $38.69^{\text {cdef }}$ & $35.79^{\text {defghi }}$ \\
\hline 1 time weeding & $34.6^{\text {efghi }}$ & $39.21^{\text {cd }}$ & $36.12 d^{\text {efgh }}$ & $34.08^{\text {ghij }}$ \\
\hline 2 times weeding & $31.5 \mathrm{ij}$ & $37.53^{\text {cdefg }}$ & $45.28^{\mathrm{b}}$ & $33.08^{\text {hij }}$ \\
\hline 3 time weeding & $34.33^{\text {fghi }}$ & $41.4^{\text {bc }}$ & $37.81^{\text {cdefg }}$ & $49.87^{\text {a }}$ \\
\hline Mean & 47.40 & & & \\
\hline LSD (5\%) & 3.37 & & & \\
\hline CV (\%) & 5.07 & & & \\
\hline
\end{tabular}

$\mathrm{LSD}=$ Least Significant Difference at $5 \%$ level; $\mathrm{CV}=$ coefficient of variation.

Means in columns followed by the same letter(s) are not significantly different at $5 \%$ level of significant

\subsubsection{Days to $50 \%$ Flowering}

The interaction effect of spacing and weeding frequency were significant $(\mathrm{P}<0.05)$ on days to $50 \%$ flowering of groundnut. The result revealed that the crops flowered earlier (31.88 days) when planted at narrow inter row spacing $(40 \mathrm{~cm} \times 10 \mathrm{~cm})$ and no weeding and flowered late (44.17 days) when planted at wider spacing $(70 \mathrm{~cm} \times 10 \mathrm{~cm})$ and three times weeding (Table 3$)$. The differences observed among the groundnut was may be due to increased resource utilization efficiency in higher plant population densities and weed competition.

Table 3: Interaction effect of inter-row spacing and weeding frequency on days to $50 \%$ flowering

\begin{tabular}{|l|c|c|c|c|}
\hline \multirow{2}{*}{ Weeding frequency } & \multicolumn{4}{|c|}{ Spacing } \\
\cline { 2 - 5 } & $\mathbf{4 0 \times 1 0 \mathbf { c m }}$ & $\mathbf{5 0 \times 1 0 c m}$ & $\mathbf{6 0 x 1 0 c m}$ & $\mathbf{7 0 x 1 0 c m}$ \\
\hline No weeding & $31.83^{\mathrm{j}}$ & $33.99^{\text {ghij }}$ & $34.57^{\text {fghi }}$ & $36.87^{\text {ef }}$ \\
\hline 1 time weeding & $32.54^{\text {ij }}$ & $33.63^{\text {hi }}$ & $36.09^{\text {efgh }}$ & $38.35^{\text {cde }}$ \\
\hline 2 times weeding & $34.42^{\text {fghu }}$ & $37.42^{\text {de }}$ & $41.16^{\text {b }}$ & $39.39^{\text {bc }}$ \\
\hline 3 time weeding & $36.37^{\text {fg }}$ & $39.72^{\text {bcd }}$ & $40.68^{\text {bc }}$ & $44.17^{\mathrm{a}}$ \\
\hline Mean & 36.99 & & & \\
\hline LSD (5\%) & 2.23 & & & \\
\hline CV (\%) & 3.99 & & & \\
\hline
\end{tabular}

LSD = Least Significant Difference at 5\% level; CV= coefficient of variation.

Means in columns followed by the same letter(s) are not significantly different at $5 \%$ level of significant

\subsubsection{Days to $90 \%$ Maturity}

The number of days required to reach physiological maturity of groundnut was highly significantly $(\mathrm{P}<0.01)$ influenced by the interaction effect of inter-row spacing and weeding frequency. Groundnut planted with the combination of $70 \times 10 \mathrm{~cm}$ with two times and three times weeding frequency takes longer time for maturity which was 165.3 and 164.09 days respectively. On the other hand, early maturity was observed on combination of 40x10cm spacing with no weeding which was 136.69 days(Table 4). The days to maturity of groundnut was generally shorter at the 
higher plant densities and low weeding frequency than at lower densities and high weeding frequency. This effect could be due to more planting density and low weeding frequency that leads to more inter and intra plant competition and earlier crop maturity rather than continuing vegetative growth.

Table 4: The interaction effect of inter-row spacing and weeding frequency on days to $90 \%$ maturity

\begin{tabular}{|l|c|c|c|c|}
\hline \multirow{2}{*}{ Weeding frequency } & \multicolumn{4}{|c|}{ Spacing } \\
\cline { 2 - 5 } & $\mathbf{4 0 \times 1 0 c m}$ & $\mathbf{5 0 \times 1 0 c m}$ & $\mathbf{6 0 x 1 0 c m}$ & $\mathbf{7 0 \times 1 0 c m}$ \\
\hline No weeding & $136.69^{\mathrm{h}}$ & $140.35^{\mathrm{g}}$ & $156.53^{\mathrm{bc}}$ & $156.07^{\mathrm{c}}$ \\
\hline 1 time weeding & $143.15^{\mathrm{f}}$ & $143.35^{\mathrm{ef}}$ & $149.47^{\mathrm{d}}$ & $158.5^{\mathrm{b}}$ \\
\hline 2 times weeding & $143.16^{\mathrm{f}}$ & $144.25^{\mathrm{ef}}$ & $150.27^{\mathrm{d}}$ & $165.30^{\mathrm{a}}$ \\
\hline 3 time weeding & $145.63^{\mathrm{e}}$ & $148.83^{\mathrm{d}}$ & $158.69^{\mathrm{b}}$ & $164.09^{\mathrm{a}}$ \\
\hline Mean & 150.27 & & & \\
\hline LSD (5\%) & 2.352 & & & \\
\hline CV (\%) & 7.94 & & & \\
\hline
\end{tabular}

$\mathrm{LSD}=$ Least Significant Difference at $5 \%$ level; $\mathrm{CV}=$ coefficient of variation.

Means in columns followed by the same letter(s) are not significantly different at $5 \%$ level of significant

\subsubsection{Leaf area index (LAI)}

Analysis of variance revealed that the interaction effect of inter-row spacing and weeding frequency on leaf area index was significant at $(\mathrm{P}<0.01)$. Leaf area index was significantly increased from 2.18to4.546 as spacing become narrow and weeding frequency become increase. As a result the highest leaf area index was recorded on $40 \times 10 \mathrm{~cm}$ with zero weeding treatment combination which was also statistically in parity with leaf area index obtained from $60 x 10 \mathrm{~cm}$ spacing with two times weeding and $60 \times 10 \mathrm{~cm}$ spacing with three times weeding and the lowest was recorded on $70 \times 10 \mathrm{~cm}$ spacing and three times weeding frequency(Table 5). Increased weeding frequencies and narrow spacing increased leaf area index .This is may be due to better control of weeds which reduced competition and increased availability of resources like nutrients, soil moisture and light provide way for higher leaf area per plant and narrow spacing enhance LAI due to less ground area.

Table 5: The interaction effect of inter-row spacing and weeding frequency on LAI

\begin{tabular}{|l|c|c|c|c|}
\hline \multirow{2}{*}{ Weeding frequency } & \multicolumn{4}{|c|}{ Spacing } \\
\cline { 2 - 5 } & $\mathbf{4 0 \times 1 0 c m}$ & $\mathbf{5 0 \times 1 0 c m}$ & $\mathbf{6 0 x 1 0 c m}$ & $\mathbf{7 0 \times 1 0 c m}$ \\
\hline No weeding & $3.03^{\mathrm{de}}$ & $3.27^{\mathrm{dc}}$ & $2.58^{\mathrm{ef}}$ & $2.18^{\mathrm{f}}$ \\
\hline 1 time weeding & $3.76^{\mathrm{bc}}$ & $3.50^{\mathrm{dc}}$ & $3.45^{\mathrm{dc}}$ & $2.37^{\mathrm{f}}$ \\
\hline 2 times weeding & $4.55^{\mathrm{a}}$ & $4.11^{\mathrm{ab}}$ & $4.46^{\mathrm{a}}$ & $2.38^{\mathrm{f}}$ \\
\hline 3 time weeding & $4.48^{\mathrm{a}}$ & $4.37^{\mathrm{a}}$ & $4.37^{\mathrm{a}}$ & $2.54 \mathrm{e}^{\mathrm{f}}$ \\
\hline Mean & 3.392 & & & \\
\hline LSD(5\%) & 0.527 & & & \\
\hline CV (\%) & 6.571 & & & \\
\hline
\end{tabular}

LSD = Least Significant Difference at $5 \%$ level; $C V=$ coefficient of variation. 
Means in columns followed by the same letter(s) are not significantly different at $5 \%$ level of significant

\subsection{Effect of Inter-Row Spacing and Weeding Frequency on Yield and Yield Components}

\subsubsection{Number of Pods Per Plant}

The main effects of inter-row spacing, weeding frequency and their interaction was highly significant $(\mathrm{P}<0.001)$ on the total number of pod per plant of groundnut. Accordingly, $60 \times 10 \mathrm{~cm}$ with three times weeding gave the highest number of pod per plant (45.003) while $40 \times 10 \mathrm{~cm}$ spacing with zero time weeding gave the lowest number of pod per plant (20.92) (Table 6). The highest pod per plant recorded by the medium spacing and two times weeding could be due to the optimum plant population per unit area and less crop-weed competition that leads to efficient use of resources. Weeding and spacing had significant effect on the number of pods per plant as weeds infestation increase and the spacing become narrower number of pods per plant decrease.

Table 6: The interaction effect of inter-row spacing and weeding frequency on number of pods per plant

\begin{tabular}{|l|c|c|c|c|}
\hline \multirow{2}{*}{ Weeding frequency } & \multicolumn{4}{|c|}{ Spacing } \\
\cline { 2 - 5 } & $\mathbf{4 0 \times 1 0 c m}$ & $\mathbf{5 0 x 1 0 c m}$ & $\mathbf{6 0 x 1 0 c m}$ & $\mathbf{7 0 \times 1 0 c m}$ \\
\hline No weeding & $20.92^{\mathrm{i}}$ & $38.73^{\mathrm{cd}}$ & $38.84^{\mathrm{cd}}$ & $33.96^{\mathrm{ef}}$ \\
\hline 1 time weeding & $24.71^{\mathrm{h}}$ & $38.66 \mathrm{c}^{\mathrm{d}}$ & $40.72^{\mathrm{bc}}$ & $31.57^{\mathrm{fg}}$ \\
\hline 2 times weeding & $30.46^{\mathrm{g}}$ & $42.24^{\mathrm{ab}}$ & $45.00^{\mathrm{a}}$ & $36.06^{\mathrm{de}}$ \\
\hline 3 time weeding & $33.63^{\mathrm{ef}}$ & $42.95^{\mathrm{ab}}$ & $43.40^{\mathrm{ab}}$ & $32.87^{\mathrm{ab}}$ \\
\hline Mean & 35.92 & & & \\
\hline LSD (5\%) & 3.04 & & & \\
\hline CV (\%) & 3.73 & & & \\
\hline
\end{tabular}

LSD = Least Significant Difference at 5\% level; CV= Coefficient of Variation.

Means in column and row followed by the same letters are not significantly different at $5 \%$ level of significant.

\subsubsection{Number of Seed Per Pod}

Main effect of inter-row spacing and weeding frequency as well as their interaction effect shows Non-significant $(\mathrm{P}>0.05)$ difference number of seed per pod of groundnut.

Table 7. The interaction effect of inter-row spacing and weeding frequency on Number of seed per pod

\begin{tabular}{|l|c|c|c|c|}
\hline \multirow{2}{*}{ Weeding frequency } & \multicolumn{4}{|c|}{ Spacing } \\
\cline { 2 - 5 } & $\mathbf{4 0 x 1 0} \mathbf{c m}$ & $\mathbf{5 0 x 1 0 c m}$ & $\mathbf{6 0 x 1 0 c m}$ & $\mathbf{7 0 x 1 0 c m}$ \\
\hline No weeding & $2.00^{\mathrm{b}}$ & $2.04^{\mathrm{ab}}$ & $2.10^{\mathrm{ab}}$ & $2.03^{\mathrm{ab}}$ \\
\hline 1 time weeding & $2.19^{\mathrm{ab}}$ & $2.17^{\mathrm{ab}}$ & $2.17^{\mathrm{ab}}$ & $2.27^{\mathrm{a}}$ \\
\hline 2 times weeding & $2.00^{\mathrm{b}}$ & $2.01^{\mathrm{b}}$ & $2.03^{\mathrm{ab}}$ & $2.13^{\mathrm{ab}}$ \\
\hline 3 time weeding & $2.15^{\mathrm{ab}}$ & $2.13^{\mathrm{ab}}$ & $2.00^{\mathrm{b}}$ & $2.00^{\mathrm{b}}$ \\
\hline
\end{tabular}




\begin{tabular}{|l|l|l|l|l|}
\hline Mean & 2.09 & & & \\
\hline LSD (5\%) & 0.25 & & & \\
\hline CV (\%) & 6.21 & & & \\
\hline
\end{tabular}

LSD = Least Significant Difference at 5\% level; CV= coefficient of variation.

Means in columns followed by the same letter(s) are not significantly different at $5 \%$ level of significant

\subsubsection{Hundred Seed Weight}

Analysis of variance revealed that the interaction effect of inter-row spacing and weeding frequency on hundred seed weight was significant at $(\mathrm{P}<0.001)$. The highest seed weight $(59.07 \mathrm{gm})$ was recorded on $70 \times 10 \mathrm{~cm}$ spacing with three time weeding followed by $(56.39 \mathrm{gm})$ on $60 \times 10 \mathrm{~cm}$ spacing with two times weeding. On the other hand, the lowest seed weight $(32.53 \mathrm{gm})$ was recorded on $40 \mathrm{X} 10 \mathrm{~cm}$ with zero spacing (Table 8). This decrease in hundred seed weight might be because of assimilates division between higher numbers of seed used in connection with the decreased inter plant competition and increasing its yield components. On the contrary, wider spaced plants with less weed computation improve the supply of assimilates to be stored in the seed, hence, the weight of hundred seeds increased.

Table 8: The interaction effect of inter-row spacing and weeding frequency on hundred seed weight (gm)

\begin{tabular}{|l|c|c|c|c|}
\hline \multirow{2}{*}{ Weeding frequency } & \multicolumn{4}{|c|}{ Spacing } \\
\cline { 2 - 5 } & $\mathbf{4 0 x 1 0 c m}$ & $\mathbf{5 0 x 1 0 c m}$ & $\mathbf{6 0 x 1 0 c m}$ & $\mathbf{7 0 x 1 0 c m}$ \\
\hline No weeding & $32.53^{\mathrm{h}}$ & $33.53^{\mathrm{h}}$ & $40.93^{\mathrm{g}}$ & $52.75^{\mathrm{dc}}$ \\
\hline 1 time weeding & $35.71^{\mathrm{h}}$ & $39.61^{\mathrm{g}}$ & $56.99^{\mathrm{ab}}$ & $55.15^{\mathrm{bc}}$ \\
\hline 2 times weeding & $44.55^{\mathrm{f}}$ & $49.02^{\mathrm{e}}$ & $52.54^{\mathrm{dc}}$ & $55.24^{\mathrm{bc}}$ \\
\hline 3 time weeding & $44.97^{\mathrm{f}}$ & $51.27^{\mathrm{de}}$ & $55.40^{\mathrm{bc}}$ & $59.07^{\mathrm{a}}$ \\
\hline Mean & 74.45 & & & \\
\hline LSD (5\%) & 3.37 & & & \\
\hline CV (\%) & 2.77 & & & \\
\hline
\end{tabular}

LSD $=$ Least Significant Difference at 5\% level; $C V=$ coefficient of variation.

Means in columns followed by the same letter(s) are not significantly different at $5 \%$ level of significant

\subsubsection{Dry Pod Yield}

The interaction effect of inter-row spacing and weeding frequency shows highly significant difference at $(\mathrm{p}<0.001)$ on dry pod Yield of groundnut. The best treatment interaction was recognized in weed-free and medium spacing treatments which is $60 \mathrm{x} 10 \mathrm{~cm}$ spacing with two times weeding giving $2,909.47 \mathrm{~kg} / \mathrm{ha}$ of dry pod yield while the narrower $(40 \times 10 \mathrm{~cm})$ and wider spacing $(70 \times 10 \mathrm{~cm})$ with minimum weed control gives the list dry pod yield $1167.75 \mathrm{~kg} / \mathrm{ha}$ and $1443.16 \mathrm{~kg} / \mathrm{ha}$ respectively (Table 9 ). The highest pod yield recorded by the medium spacing and weed-free treatment was probably due to lower competition for available resources and optimum plant population. Increasing plant density to optimum level and controlling of weed increased dry pod yield per hectare. 
Table 9: The interaction effect of inter-row spacing and weeding frequency on dry pod yield $(\mathrm{Kg} / \mathrm{ha})$

\begin{tabular}{|l|c|c|c|c|}
\hline \multirow{2}{*}{ Weeding frequency } & \multicolumn{4}{|c|}{ Spacing } \\
\cline { 2 - 5 } & $\mathbf{4 0 x 1 0 c m}$ & $\mathbf{5 0 \times 1 0 c m}$ & $\mathbf{6 0 x 1 0 c m}$ & $\mathbf{7 0 x 1 0 c m}$ \\
\hline No weeding & $1167.75^{\mathrm{h}}$ & $1795.04^{\mathrm{f}}$ & $2522.21^{\mathrm{bcd}}$ & $1443.16^{\mathrm{g}}$ \\
\hline 1 time weeding & $2511.27^{\mathrm{bcd}}$ & $2478.25^{\mathrm{bcd}}$ & $2984.14^{\mathrm{a}}$ & $2038.15^{\mathrm{e}}$ \\
\hline 2 times weeding & $2669.99^{\mathrm{b}}$ & $2328.52^{\mathrm{d}}$ & $2909.47^{\mathrm{a}}$ & $2631.63^{\mathrm{bc}}$ \\
\hline 3 time weeding & $2461.94^{\mathrm{cd}}$ & $2411.91^{\mathrm{d}}$ & $2889.17^{\mathrm{ab}}$ & $2013.25^{\mathrm{e}}$ \\
\hline Mean & 2367.989 & & & \\
\hline LSD (5\%) & 193.7 & & & \\
\hline CV (\%) & 3.245 & & & \\
\hline
\end{tabular}

$\mathrm{LSD}=$ Least Significant Difference at $5 \%$ level; $\mathrm{CV}=$ coefficient of variation.

Means in columns followed by the same letter(s) are not significantly different at $5 \%$ level of significant

\subsubsection{Seed Yield}

The interaction effect of spacing and weeding frequency shows significant effect $(\mathrm{p}<0.001)$ on seed yield. The highest treatment interaction for seed yield $(2,360.15 \mathrm{~kg} / \mathrm{ha})$ was recognized in $60 \times 10$ spacing two times weeding, while the $40 \times 10 \mathrm{~cm}$ and $70 \times 10 \mathrm{~cm}$ spacing with zero weeding had the least $922.21 \mathrm{~kg} / \mathrm{ha}$ and $943.8 \mathrm{~kg} / \mathrm{ha}$ seed yield respectively (Table 10). Decreasing plant spacing and weeding frequency decreased seed yield per hectare due to competition.

Table 10: The interaction effect of inter-row spacing and weeding frequency on seed yield (Kg/ha)

\begin{tabular}{|l|c|c|c|c|}
\hline \multirow{2}{*}{ Weeding frequency } & \multicolumn{4}{|c|}{ Spacing } \\
\cline { 2 - 5 } & $\mathbf{4 0 \times 1 0} \mathbf{c m}$ & $\mathbf{5 0 x 1 0 c m}$ & $\mathbf{6 0 x 1 0 c m}$ & $\mathbf{7 0 \times 1 0 c m}$ \\
\hline No weeding & $922.21^{\mathrm{i}}$ & $1125.17^{\mathrm{h}}$ & $1436.29^{\mathrm{ef}}$ & $943.8^{\mathrm{i}}$ \\
\hline 1 time weeding & $1454.95^{\mathrm{ef}}$ & $1074.20^{\mathrm{hi}}$ & $1837.55^{\mathrm{c}}$ & $1584.54^{\mathrm{de}}$ \\
\hline 2 times weeding & $1136.17^{\mathrm{gh}}$ & $1179.20^{\mathrm{gh}}$ & $2360.15^{\mathrm{a}}$ & $1862.42^{\mathrm{c}}$ \\
\hline 3 time weeding & $1239.61^{\mathrm{gh}}$ & $1305.94^{\mathrm{fg}}$ & $2089.55^{\mathrm{b}}$ & $1717.63^{\mathrm{cd}}$ \\
\hline Mean & 1454.15 & & & \\
\hline LSD (5\%) & 177.65 & & & \\
\hline CV (\%) & 4.276 & & & \\
\hline
\end{tabular}

LSD = Least Significant Difference at 5\% level; $C V=$ coefficient of variation Means in columns followed by the same letter(s) are not significantly different at $5 \%$ level of significant

\subsubsection{Harvest index (HI)}

The main effect of spacing showed none significant effect on the harvest index of groundnut, While the effect of weeding frequency showed highly significant $(\mathrm{P}<0.001)$ effect on harvest index. Among the weeding frequency, the highest harvest index $(28.41 \%)$ was obtained from three times weeding. While the lowest harvest index $(16.75 \%)$ was found from none weeded treatment (Table 11). 


\subsection{Effect of Inter-Row Spacing and Weeding Frequency on Quality Parameters}

\subsubsection{Protein Content}

The main effects of weeding frequency and spacing on protein content was highly significant $(\mathrm{P}<0.001)$ while the interaction effect was not significant. The highest protein content $(20.87 \%)$ was recorded from three time weeding while the lowest $(15 \%)$ was recorded from none weeded treatment (Table 11). These results could be due to the better $\mathrm{N}$ utilization by groundnut plants under minimum weed computation.

With regard to spacing the highest protein content $(20.2833 \%)$ was recorded from $70 \times 10 \mathrm{~cm}$ spacing while the lowest $(18.4692 \%)$ was from $40 x 10 \mathrm{~cm}$ spacing (Table 11$)$. These results could be attributed to that in wider spacing the plants is able to from more metabolites to synthesize more protein in the seeds and the activity of protein synthesis is higher than at narrow spacing.

\subsubsection{Oil Content}

The main effects of weeding frequency were highly significant $(\mathrm{P}<0.01)$ while main effect of spacing and interaction effect was not significant on oil content. The highest oil content $32.48 \%$ was recorded from three times weeding frequency while the lowest $27.54 \%$ was recorded from none weeded treatment (Table 11).Improvement in the oil content of groundnut as weeding frequency increase could be attributed to better nutrition of the groundnut which plays a crucial role in improving oil content of the seed.

Table 11: Main effects inter-row spacing and weeding frequency on harvest index, oil content and protein content

\begin{tabular}{|l|c|c|c|}
\hline & HI & Ol & Pr \\
\hline Weeding frequency & & & \\
\hline No weeding & $16.75^{\mathrm{c}}$ & $27.535^{\mathrm{b}}$ & $15.00^{\mathrm{c}}$ \\
\hline 1 time weeding & $23.083^{\mathrm{b}}$ & $29.389^{\mathrm{ab}}$ & $19.7658^{\mathrm{b}}$ \\
\hline 2 times weeding & $28.17^{\mathrm{ab}}$ & $32.336^{\mathrm{a}}$ & $20.2775^{\mathrm{ab}}$ \\
\hline 3 time weeding & $28.417^{\mathrm{a}}$ & $32.483^{\mathrm{a}}$ & $20.816^{\mathrm{a}}$ \\
\hline Mean & 24.104 & 30.435 & 18.965 \\
\hline LSD & 5.213 & 3.376 & 0.8282 \\
\hline CV & 25.93 & 13.304 & 5.237 \\
\hline Spacing & & & \\
\hline $40 x 10 \mathrm{~cm}$ & $22.917 \mathrm{a}$ & $30.208^{\mathrm{a}}$ & $18.4692^{\mathrm{b}}$ \\
\hline $50 x 10 \mathrm{~cm}$ & $25.583 \mathrm{a}$ & $29.286^{\mathrm{a}}$ & $19.036^{\mathrm{b}}$ \\
\hline $60 x 10 \mathrm{~cm}$ & $25.66 \mathrm{a}$ & $31.396^{\mathrm{a}}$ & $19.07^{\mathrm{b}}$ \\
\hline $70 x 10 \mathrm{~cm}$ & $22.250^{\mathrm{a}}$ & $30.553^{\mathrm{a}}$ & $20.2833^{\mathrm{a}}$ \\
\hline Mean & 24.104 & 30.435 & 18.965 \\
\hline LSD $(5 \%)$ & Ns & $\mathrm{Ns}^{2}$ & 0.8282 \\
\hline CV $(\%)$ & 25.93 & 13.304 & 5.237 \\
\hline
\end{tabular}

LSD = Least Significant Difference at 5\% level; CV= coefficient of variation; NS, Non-significant. Means in columns followed by the same letter(s) are not significantly different at $5 \%$ level of significant. 


\section{Conclusion and Recommendation}

Groundnut or peanut (ArachishypogaeaL.) which belongs to family Leguminosaegenus Arachisis one of the world's principal oil seed crops rated fourth for its oil production (FAO, 2011). Groundnut production is affected by different biotic and abiotic factors among them the main problems limiting production of groundnut are poor cultural practices (especially the practice of wide spacing) as well as inadequate weed management. In view of this, Roba groundnut variety with four weeding frequency ( 0 wedding, 1 weeding, 2 weeding and 3 weeding) in ten days interval and four inter row spacingS1 $(40 \mathrm{~cm} \times 10 \mathrm{~cm}), \mathrm{S} 2(50 \mathrm{~cm} \times 10 \mathrm{~cm}), \mathrm{S} 3$ plants ha-1 $(60 \mathrm{~cm} \times 10$ $\mathrm{cm})$ and S4 $(70 \mathrm{~cm} \times 10 \mathrm{~cm})$ were evaluated during the 2017/2018 rain season to examine phonological, yield performance and quality of the groundnut.

Selection based on phenological performance revealed that treatment $70 \times 10 \mathrm{~cm}$ with three times weeding score highest plant height on the other hand, early flowering, and maturity was recorded on $40 \times 10 \mathrm{~cm}$ spacing with zero weeding. High LAI was obtained from combination of $40 \times 10 \mathrm{~cm}$ spacing with two times weeding frequency. Furthermore, spacing of $60 \times 10 \mathrm{~cm}$ with two times weeding gave the highest number of pod per plant, dry pod yield and seed yield while $70 \times 10 \mathrm{~cm}$ spacing with three time weeding was superior in hundred seed weight. On the other hand, three times weeding frequency gives the highest harvest index and oil content but inter-row spacing didn't show significant difference on these parameters. In terms of protein content the highest content was recorded on three times weeding frequency and $70 x 10 \mathrm{~cm}$ spacing but there interaction effect was none significant.

Generally, the present study revealed that inter-row spacing and weeding frequency have strong influence on groundnut yield. Proper spacing and weeding is very important to get better yield and quality groundnut.

In conclusion from the study, Acc60x 10cm spacing with two times weeding was found to be better in yield and yield component and quality parameters. However, as this is one season experiment at one location, it has to be repeated over locations and seasons considering intra-row spacing and weeding frequency to reach at a more reliable conclusion.

\section{References}

[1] Ahmed M. El Naim*, Mona A. Eldouma, Elshiekh A. Ibrahim, Moayad, M. B. Zaied 2011. Influence of Plant Spacing and Weeds on Growth and Yield of Peanut (ArachishypogaeaL) in Rainfed of Sudan.Advances in Life Sciences. 2011; 1(2): 45-48

[2] Allam AY. 2002. Effect of gypsum, nitrogen fertilization and hill spacing on seed and oil yields of sesame cultivated on sandy soil. Agron .Dept.,J., 69:465-469.Ind.J Agron. 25:562-563.

[3] El Naim, A, M. and Jabereldar, A. A. 2010. Effect of Plant density and cultivar on growth and yield of cowpea (VignaunguiculataL.Walp). Australian Journal of Basic and Applied Sciences, 4(8): 3148-3153.

[4] El Naim, A. M. and Ahmed, S. E. 2010. Effect of weeding frequencies on growth and yield of two roselle (Hibiscus sabdariffaL.) Varieties under rain fed. Australian Journal of Basic and Applied Sciences, 4(9): 4250-4255, 
[5] El Naim, A. M., El day, E. M. and Ahmed, A. A. 2010b. Effect of plant density on the performance of some sesame (Sesamumindicum L) cultivars under Rain -fed. Research Journal of Agriculture and Biological Sciences, 6(4): 498-504

[6] Khidir M. O. 1997. Oil seed crops in the Sudan. Khartoum University press, Khrtoum, dan

[7] El Naim, A. M., Hagelsheep, A. M., Abdelmuhsin, M. E. and Abdalla, A. E. 2010c. Effect of Intrarow spacing on growth and yield of three cowpea (VignaunguiculataL. Walp.) varieties under rainfed. Research Journal of Agriculture and Biological Sciences, 6(5): 623-629

[8] Kathirvelan, P. and P. Kalaiselvan, P. (2007). Studies on Agro Management Techniques for Confectionery Groundnut under Irrigated Conditions. Research Journal of Agriculture and Biological Sciences, 3(1): 52-58.

[9] Kwadwo Gyasi Santo, Joseph Sarkodie-Addo, Ibrahim Yussif Jnr and Kwabena Acheremu 2016. Yield Response of Groundnut (Arachishypogaea) to Weeding Regime and Plant Spacing Journal of Biology, Agriculture and HealthcareVol.6, No.6 (65-73)

[10] Gibbons, R.W., Bunting, A.H. and Smartt, J. (1972). The classification of varieties of groundnut (Arachishypogaea). Euphytica, 21: 78-85.

[11] Morrison, M.J., Mc Vetty, P.B.E. and Scarth, R. 1990. Effect of altering plant density on growth characteristics of summer rape. Canadian Journal of Plant Science, 70: 139-149.

[12] Ramesh, R. and Sabale, R.N. (2001). Phosphorus and plant population management in groundnut (Arachishypogaea) - fenugreek (Trigonellafoenum - graecum) cropping system. Indian J. Agron., 46(4): 621-626.

[13] Turk, M.A, Tawaha, A. M. and El-shatnawi, M.K.J. 2003. Response of lentil (Lensculinaris) the absence of moisture stress. Journal of Agricultural Crop Science, 189: 1-6

[14] Daniel, E. 2009. Groundnut research. pp. 1-3. In: Presentation for Workshop, Werer Agricultural Research Center, Ethiopia.

[15] EARO (Ethiopian Agricultural Research Organization),2000. Strategies and priorities for lowland oil crops research. Addis Ababa, Ethiopia. ed., India.

[16] Monneveux, P., Zaidi, P.H. and Sanchez, C. 2005. Population density and low nitrogen affectsyield. - Associated Traits in Tropical Maize. Crop Science, 45: 2-7.

[17] Bedry K. A. 2007. Effect of weeding regimes on faba bean (viciafaba 1.) yield in the Northern State of Sudan. University of Khartoum Journal of Agricultural Science, 15: 220-231

[18] Konlan S., Sarkodie-Addo J. A.E. and Kombiok M.J., (2013b) Groundnut (ArachishypogaeaL.) varietal response to spacing in the Guinea savanna agro-ecological zone of Ghana: Nodulation and nitrogen fixation, Agric. Biol. J. North America, 4(3):324-335.

[19] Konlan S., Sarkodie-Addo. A. E. and Kombiok M.J., (2013a) Groundnut (ArachishypogaeaL.) varietal response to spacing in the Guinea savanna agro-ecological zone of Ghana: Growth and yield, Afr. J.Agric. Res. 8(22):2769-2777.

[20] Mubarak H. A. 2004. Studies on weed management in irrigated groundnuts (Arachishypogaea L). in Sudan. Ph.D. Thesis. Faculty of Agricultural Sciences, University of Gezira, Wad Medani, Sudan,

[21] Joshi K. R. 2004. Effect of time of weeding and levels of N and P2 P5 fertilizers on the grain yield of maize. Nepal Agric. Res. J. 5, 69-70.

[22] Gulluoglu, L.; Bakal, H.; EL-Sabagh, A. and Arioglu, H. (2017). Soybean managing for maximize production: Plant population density affects seed yield and some agronomical traits in main cropped soybean production. J. of Experimental Biology \& Agric. Sci., 5(1): 31-37.

[23] Ibrahim, S.A. and Kandil, H. (2007). Growth, yield and chemical constituents of soybean (Glycin max L.) plants as affected by plant spacing under different irrigation intervals. Res. J. Agric. \& Biol. Sci. 3(6):657-663.

[24] Peer, F.A.; Hassan, B.; Lone, B.A.; Qayoom, S.; Ahmad, L. and Khanday, B.A. (2013). Effect of weed control methods on yield and yield attributes of soybean. Afr. J. Agric. Res., 8(48): 61356141. 
[25] Rajkumari; Khaswan, S.L.; Kumar, A.; Kumar, K. and Thori, S.S. (2017a). Effect of different tillage practices and weed management on weed dynamics, productivity and quality of soybean [Glycine max (L.) Merrill]. Internat. J. Chemical Studies.5(4): 1695-1697.

[26] Seadh, S.E. and Abido, W.A.E. (2013). How soybean cultivars canopy affect yield and quality. J. of Agron.: 1-7.

[27] SAS Institute Inc., 2008. Statistical Analysis System, Version 9.2. Cary, North Carolina, USA.

[28] Soliman, I.E.; Morsi, A.R. and Azza, E.K. (2015). Effect of competitive abilities of some soybean genotypes, plant density and weed con- trol treatments on soybean (Gly-cine max L.) and its associated weeds. J. Plant Production, Man- soura Univ., 6(8): 1413-1429.

[29] Central Statistical Agency (CSA). Agricultural sample survey in 20012/2013. Addis Ababa, Ethiopia; 2014.

[30] Adugna Wakjira, 1992. Performance of elite groundnut varieties in Ethiopia. Pages 22-24 in proceedings of the fifth regional groundnut workshop for southern Africa 9-12 March 1992, Lilongwe, Malawi Nageswara Rao, R.C, and Subrahmanyam, P, eds. J. Pataneheru, A.P, 502, 324 India: International Crop Research Institute for the Semi-Arid Tropics.

\footnotetext{
*Corresponding author.

E-mail address: biftuumer22@ gmail.com/besuloza@gmail.com
} 